\section{IAC Catuaí SH3 - a dwarf Arabica coffee cultivar with leaf rust resistance and drought tolerance}

\section{Luiz Carlos Fazuoli ${ }^{1}$, Masako Toma Braghini ${ }^{1}$, Maria Bernadete Silvarolla ${ }^{1}$, Wallace Gonçalves ${ }^{1}$, Júlio César Mistro ${ }^{1}$, Paulo Boller Gallo ${ }^{1}$ and Oliveiro Guerreiro Filho ${ }^{1^{*}}$}

\begin{abstract}
The cultivar IAC Catuai SH3 was developed by the pedigree method, from the recombination of the coffee tree $\mathrm{H}$ 2077-2-5-46, of the Catuai Vermelho germplasm, with accession IAC 1110-8, from the exotic cultivar BA10. Cultivar IAC Catuai SH3 is high-yielding, resistant to coffee leaf rust and tolerant to drought.
\end{abstract}

Keywords: Coffea arabica, cup quality, durable resistance, Hemileia vastatrix.

\section{INTRODUCTION}

Coffee leaf rust, caused by Hemileia vastatrix Berkeley and Broome is the main disease of coffee (Zambolim et al. 2002, Zambolim et al. 2005). Detected in Brazil in 1970, nowadays 17 physiological races of the fungus are found known, while 28 other exotic races were already described by the International Center for Coffee Rust (CIFC) in Oeiras, Portugal (Várzea et al. 2002).

Nine resistance genes, four of which from Coffea arabica $\left(\mathrm{S}_{\mathrm{H}} 1, \mathrm{~S}_{\mathrm{H}} 2, \mathrm{~S}_{\mathrm{H}} 4\right.$, and $\left.S_{H} 5\right)$, one from $C$. liberica $\left(S_{H} 3\right)$ and the others from $C$. canephora $\left(S_{H} 6\right.$ to $\left.S_{H} 9\right)$, have been used individually or together in the development of resistant cultivars, as a strategy to combat the pathogen (Bettencourt et al. 1992, Bettencourt and Fazuoli 2008).

The resistance of several Brazilian Arabica coffee cultivars, developed as described above, was overcome after around 10 years on average, by the appearance of new physiological races of the fungus (Del Grossi et al. 2013). In Brazil, only the resistance conferred by gene $\mathrm{S}_{\mathrm{H}} 3$ has not yet been overcome by the pathogen.

Accession IAC 1110-8, a single tree of the exotic cultivar BA10, incorporated in 1953 in the IAC germplasm bank, and carrier of gene $\mathrm{S}_{\mathrm{H}} 3$, has a durable resistance to the disease, and is to date resistant to the fungus races occurring in Brazil.

This study describes the development of a new Arabica coffee cultivar, derived from the hybridization of coffee tree $\mathrm{H}$ 2077-2-5-46, from the Catuai germplasm with accession IAC 1110-8, of the exotic cultivar BA10.

\section{BREEEDING PROCESS}

The Arabic coffee cultivar IAC Catuaí SH3 was developed at the Agronomic Institute (IAC), Campinas, SP, Brazil, from a cross carried out in 1967 between a coffee trees of the line H 2077-2-5-46 of the germplasm released later, in 1972,
Crop Breeding and Applied Biotechnology 19:3, 356-359, 2019 Brazilian Society of Plant Breeding. Printed in Brazil http://dx.doi.org/10.1590/1984$70332019 v 19 n 3 c 48$ 
as cultivar Catuaí Vermelho and accession IAC 1110-8 of the exotic cultivar BA10, respectively, used as female and male parents (Figure 1).

The hybridization had the objective of combining complementary agronomic traits of the parents in a new cultivar. The coffee tree $\mathrm{H}$ 2077-2-5-46 has a compact architecture, with short internodes on both the orthotropic stem and plagiotropic branches, due to the homozygous expression of the allele caturra (Carvalho et al. 1984); but highly productive, and susceptible to coffee leaf rust. On the other hand, IAC 1110-8, a single plant of selection BA10, is highly resistant to this disease. The germplasm was imported by IAC in 1953, from the US Department of Agriculture, and was subjected to selection at the Experimental Station in Balehonnur, India.

The rust resistance present in accession IAC 1110-8 is a result of introgression of genes from $C$. liberica (Bettencourt and Carvalho 1968); the plants have a tall tree size, good yield and high incidence of elephant beans.

Cultivar IAC Catuaí SH3 was developed by the pedigree method, after seven generations of selection, in progeny trials in coffee-producing regions of São Paulo, in which diverse traits such as yield, plant vigor, fruit size, ripening cycle, rust resistance, bean output, percentage of flat, peaberry and elephant beans, 100-bean weight of the flat type, drought tolerance, resistance to brown-eye spot and cup quality were evaluated.

The new cultivar was registered in 2015 by the National Register of Cultivars, of the Ministry of Agriculture, Livestock and Supply (RNC/MAPA). The name IAC Catuaí SH3 was attributed to the distinct, homogeneous and stable population, carrying the $S_{H} 3$ gene in homozygosis $\left(S_{H} 3 S_{H} 3\right)$, a trait that confers resistance to the rust races identified to date in Brazil.

\section{PERFORMANCE}

The performance of cultivar IAC Catuaí SH3 was evaluated in rainfed cultivation in producing regions of the State of São Paulo. The data of the mean coffee yield in bags of green coffee per hectare and per year and the relative yield in comparison with the experimental control, in trials carried out in Mococa and Franca, are shown in Table 1.

In a rainfed experiment, planted in 2006 in the Polo Nordeste Paulista, Mococa, SP, the mean yield of five harvests of cultivar IAC Catuaí SH3 was 39.1 bags of green coffee ha-1 $\mathrm{yr}^{-1}$; cultivar Catuaí Amarelo IAC 62, an experimental control, produced 29 bags of green coffee ha-1 $\mathrm{yr}^{-1}$. In another experiment, also without irrigation, planted in Franca, SP, in 2005,

Table 1. Mean productivity in green coffee bags per hectare per year and relative yield of cultivar IAC Catuaí SH3 compared to Catuaí Amarelo IAC 62 and Catuaí Vermelho IAC 99 cultivars, respectively in Mococa and Franca, SP

\begin{tabular}{|c|c|c|c|c|}
\hline Location & Cultivar & Yield (bags ha-1 $\mathrm{yr}^{-1}$ ) & Relative yield (\%) & Rust resistance $^{1}$ \\
\hline & & & & Points \\
\hline \multirow{2}{*}{ Mococa $^{2}$} & IAC Catuaí SH3 & 39.1 & 135 & 0 \\
\hline & Catuaí Amarelo IAC 62 & 29.0 & 100 & 4 \\
\hline \multirow{2}{*}{ Franca $^{3}$} & IAC Catuaí SH3 & 57.0 & 142 & 0 \\
\hline & Catuaí Vermelho IAC 99 & 40.3 & 100 & 4 \\
\hline
\end{tabular}

${ }^{1}$ Evaluation on a 0-4 scale, where 0 and 1 = resistant; 2 = moderately resistant, $3=$ moderately susceptible and $4=$ susceptible; ${ }^{2} \mathrm{Average}$ of five harvests; ${ }^{3} \mathrm{Average}$ of six harvests. 
Table 2. Plant vigor, bean output, ripening cycle, and bean types of cultivar IAC Catuaí SH3 compared to Catuaí Vermelho IAC 99 cultivar, in Franca, SP

\begin{tabular}{|c|c|c|c|c|c|c|}
\hline \multirow{2}{*}{ Cultivar } & \multirow{2}{*}{ Vigor $^{1}$} & \multirow{2}{*}{ Bean output $^{2}$} & \multirow{2}{*}{ Ripening cycle } & \multicolumn{3}{|c|}{ Bean type } \\
\hline & & & & Flat & Peaberry & Elephant \\
\hline & Points & $\%$ & & \multicolumn{3}{|c|}{ 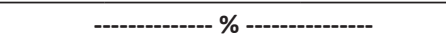 } \\
\hline IAC Catuaí SH3 & 9 & 48.2 & Medium to late & 90.0 & 6.5 & 3.5 \\
\hline
\end{tabular}

${ }^{1}$ Evaluation on a 1-10 point scale, where 1 = slightly vigorous coffee trees and 10 = very vigorous coffee trees; 2 (Green coffee weight/dry fruit weight)*100.

cultivar IAC Catuaí SH3 had a mean yield over five harvests of 57 bags; cultivar Catuaí Vermelho IAC 99, used as control, produced 40.3 bags of green coffee $\mathrm{ha}^{-1} \mathrm{yr}^{-1}$. Assigning a value of 100 to the yield of each cultivar used as control, the relative yields of cultivar IAC Catuaí SH3 were higher at both locations, 35\% in Mococa, SP and 42\% in Franca, SP.

The plant resistance to coffee rust was evaluated in the same experiments, on a 0-4 scale, where 0 and 1 were attributed to resistant; 2 to moderately resistant; 3 to moderately susceptible and 4 to susceptible coffee trees (Mendonça et al. 2016). Coffee trees of cultivar Catuaí Amarelo IAC 62, in Mococa, SP and of cultivar Catuaí Vermelho IAC 99, in Franca, SP were classified as susceptible to coffee leaf rust, classified by 4 points on the disease severity scale. At the same locations, no lesions were observed on plants of cultivar IAC Catuaí SH3, which were classified as resistant (Table 1).

\section{OTHER TRAITS}

Information related to other agronomic and technological characteristics of the new cultivar are listed in Tables 2 and 3.

Cultivar IAC Catuaí SH3 is very vigorous and has an intermediate ripening cycle between the medium and late classes used in the table of minimum descriptors for cultivar protection of MAPA. The bean output, relation between the green coffee weight and dry fruits weight is $48.2 \%$, similarly to that of Catuaí Vermelho IAC 99 . The percentage of flat beans is $90.0 \%$ and the incidence of elephant beans lower than $5 \%$ (Table 2), as recommended for the release of new commercial cultivars of the species.

The vigor and turgescence of coffee trees of the cultivars IAC Catuaí SH3, IAC 125 RN and Obatã IAC 1669-20 were visually evaluated in the field, after prolonged drought in Campinas, SP (Table 3), respectively, on 1 - 10 scales, were 1 $=$ slightly vigorous plants and $10=$ very vigorous plants and $1=$ withered leaves and $10=$ turgid leaves.

The mean vigor of cultivar IAC Catuaí SH3 was 8.3 points, while the experimental controls had slightly lower values, i.e., 7.0 for cultivar IAC $125 \mathrm{RN}$ and 8.0 for cultivar Obatã IAC 1669-20. The mean turgescence index evaluated after prolonged drought was 7.7 points for cultivar IAC Catuaí SH3 while the controls were more sensitive, with 5.0 and 5.3 for cultivars IAC 125 RN and Obatã IAC 1669-20, respectively.

Bean samples of cultivar IAC Catuaí SH3 used in sensory evaluations carried out in 2016 by specialists reached an average of 85,5 points on the scale of the Specialty Coffee Association of America (SCAA), evidencing the good cup quality of the cultivar.

Morphological, technological and agronomic characteristics of cultivar IAC Catuaí SH3 with the respective descriptions are shown in Table 4.

\section{SEED MAINTENANCE AND DISTRIBUTION}

Cultivar IAC Catuaí SH3 was registered by MAPA/ RNC, on November 11, 2015 (Registration no. 34813), and granted temporary protection by the National Plant Protection System (SNPC) MAPA/SNPC on December 28, 2016 (Certificate no. 20160296). The IAC is responsible for the production and distribution of genetic seeds.

Table 3. Mean indices of visual evaluation of vigor and turgescence of the cultivars evaluated in the experiment on the Fazenda Monte D'este, in Campinas, SP

\begin{tabular}{lcc}
\hline \multicolumn{1}{c}{ Cultivar } & Vigor $^{1}$ & \multicolumn{2}{c}{ Turgescence index } \\
\hline
\end{tabular}

${ }^{1}$ Evaluation of coffee trees on a $1-10$ scale, where 1 = slightly vigorous and $10=$ very vigorous; ${ }^{2} 1$ - 10 scale, 1 for withered leaves and 10 turgid leaves; ${ }^{3}$ Experimental control. 
IAC Catuaí SH3 - a dwarf Arabica coffee cultivar with leaf rust resistance and drought tolerance

Table 4. Morphological, technological and agronomic traits of cultivar IAC Catuaí SH3, with the respective descriptions

\begin{tabular}{|c|c|}
\hline Traits & Descriptions $^{1}$ \\
\hline Size (tree height) & Short (='Catuaí') \\
\hline Canopy radius & Between medium (='Catuaí') and large (='Acaiá') \\
\hline Canopy architecture & Cylindric (=`Catuaí') \\
\hline Internode length & Between medium (='Catuaí') and long (='Mundo Novo') \\
\hline Intensity plagiotropic branching & High (=`Catuaí') \\
\hline Young leaf color & Green (='Catuaí') \\
\hline Leaf shape & Elliptical \\
\hline Undulation of the leaf margin & Between slight and moderate (='Catuaí) \\
\hline Color of ripe fruits & Red murrey \\
\hline Fruit shape & Oblong (=‘Mundo Novo') \\
\hline Fruit size & Between medium (='Mundo Novo') and large (='Acaiá') \\
\hline Rust resistance $^{2}$ & High resistance \\
\hline Nematode resistance & Susceptible \\
\hline Reaction to Brown Eye Spot ${ }^{3}$ & Susceptible \\
\hline Cup quality & Similar to Catuaí \\
\hline
\end{tabular}

${ }^{1}$ Obatã, Catuaí, Mundo Novo, and Acaiá are Brazilian cultivars of Coffea arabica; ${ }^{2}$ Hemileia vastatrix Berkeley and Broome; ${ }^{3}$ Cercospora coffeicola Berkeley and Cooke.

\section{ACKNOWLEDGEMENTS}

The authors are grateful to the Brazilian Coffee Research and Development Consortium (CBP\&D/Café) for financial support and a research scholarship to LCF and MTB, and indebted to the National Council for Scientific and Technological Development (CNPq) for a research scholarship to OGF (CNPq DT 308.634/2016-0).

\section{REFERENCES}

Bettencourt AJ and Carvalho A (1968) Melhoramento visando a resistência do cafeeiro à ferrugem. Bragantia 27: 35-68.

Bettencourt AJ and Fazuoli LC (2008) Melhoramento genético de Coffea arabica L. Transferência de genes de resistência a Hemileia vastatrix do Híbrido de Timor para a cultivar Villa Sarchí de Coffea arabica. Documentos IAC 84: 1-20.

Bettencourt AJ, Lopes J and Palma S (1992) Factores genéticos que condicionam a resistência às raças de Hemileia vastatrix Berk. et $\mathrm{Br}$. dos clones-tipo dos grupos 1, 2 e 3 de derivados de Híbrido de Timor. Brotéria Genética 13: 185-194.

Carvalho A, Medina Filho HP, Fazuoli LC and Costa WM (1984) Genética de Coffea: XXVI. Hereditariedade do porte reduzido do cultivar Caturra. Bragantia 43: 443-458.

Del Grossi L, Sera T, Sera GH, Fonseca ICB, Ito DS, Shigueoka LH, Andreazi E and Carvalho FG (2013) Rust resistance in Arabic coffee cultivars in northern Paraná. Brazilian Archives of Biology and Technology
56: 27-33.

Mendonça APN, Nonato JVA, Andrade VT, Fatobene BJR, Braghini MT, Prela-Pantano A, Guerreiro Filho, O (2016). Coffea arabica clones resistant to coffee leaf miner. Crop Breeding and Applied Biotechnology 16: 42-47.

Várzea VMP, Rodrigues-Júnior CJ, Silva MCML, Gouveia M, Marques DV, Guerra-Guimarães L and Ribeiro A (2002) Resistência do cafeeiro a Hemileia vastatrix. In Zambolim L (ed) $\mathrm{O}$ estado da arte de tecnologias na produção de café. Editora UFV, Viçosa, p. 297-320.

Zambolim L, Vale FXR, Costa H, Pereira AA and Chaves GM (2002) Epidemiologia e controle integrado de ferrugem do cafeeiro. In Zambolim L (ed) $\mathbf{O}$ estado da arte de tecnologias na produção de café. Editora UFV, Viçosa, p. 369-450.

Zambolim L, Vale FXR and Zambolim EM (2005) Doenças do Cafeeiro. In Kimati H, Amorim L, Rezende JAM, Bergamim Filho A and Camargo LEA (eds) Manual de Fitopatologia: Doenças das Plantas Cultivadas. Editora Agronômica Ceres, São Paulo, p. 165-180. 